\title{
PENUMBUHAN RASA NASIONALISME DAN CINTA BUDAYA INDONESIA MELALUI PROGRAM "KAMSI" PADA SISWA SMP NEGERI 1 BATU
}

\author{
Syahrul Hadiyatullah, Nurbani Yusuf, Nurul Zuriah \\ FKIP Universitas Muhammadiyah Malang \\ Email : syahrulroma27@gmail.com
}

\begin{abstract}
ABSTRAK
Penelitian ini bertujuan untuk mengetahui dan mendeskripsikan penumbuhkan rasa nasionalisme dan cinta budaya Indonesia melalui program Kamis Kreasi pada sisa SMP Negeri 1 Batu. Penelitian ini menggunakan pendekatan kualitatif dan jenis penelitian ini adalah deskriptif. Subyek penelitian ini adalah siswa-siswi SMP Negeri 1 Batu (Kelas VIII F).Penelitian ini dilaksanakan di SMP Negeri 1 Batu pada tanggal 02 April 2018-10 Mei 2018. Penelitian ini menggunakan teknik pengumpulan data yaitu metode observasi, metode wawancara dan studi dokumentasi. Instrumen penelitian ini adalah dengan menggunakan panduan wawancara, pedoman observasi dan dokumentasi. Teknik analisis data pada penelitian ini adalah dengan pengumpulan data, reduksi data, penyajian data, dan penarikan kesimpulan. Keabsahan data penelitian ini menggunakan triangulasi sumber dan triangulasi teknik. Hasil penelitian menunjukkan bahwa, penumbuhan rasa nasionalisme dan cinta budaya Indonesia melalui program Kamsi dilakukan dengan proses latihan dan pertunjukan kesenian Teater Calonarang dan seni tari Reog Ponorogo di kelas VIII F SMP Negeri 1 Batu.
\end{abstract}

Kata Kunci : Nasionalisme, Kebudayaan, Kamsi.

\begin{abstract}
This research aimed at knowing and describing about the rising sense of nationalism and love for Indonesian culture through Kamis Kreasi (Kamsi) program toward the students of SMP Negeri 1 Batu. The research method used was descriptive qualitative. The research subject was the students of SMP Negeri 1 Batu (VIII F Class). This research was conducted at SMP Negeri 1 Batu started from April 2 to May 10 2018. The technique used of this research was observation, interview and documentation. The instrument used interview, observation and documentation guide. The data analysis used was data collection, data reduction, data presentation and conclusion. To validate the data, the researcher used source and technique triangulation. The result of this research was to build a sense of nationalism and love for Indonesian culture through Kamsi program done by training and showing the Calonarang theater and Reog Ponorogo Dance at class of VIII F SMP Negeri 1 Batu.
\end{abstract}

Keywords: Nationalism, Culture, Kamsi

\section{PENDAHULUAN}

Globalisasi merupakan proses tatanan masyarakatyang tidak mengenal batas wilayah. Jaman globalisasi ditandai dengan makin menipisnya batas wilayah,paham sekat kelompok serta makin mengecilnya berbagai perbedaan yang ada di setiap negara, baik yang berhubungan dengan sosial budaya, ekonomi, politik pertahanan keamanan serta teknologi. Menurut Sujanto (2007:10) globalisasi adalah sebuahdesakan paham dari negara-negara yang kuat secarapolitik dan ekonomi, yang memiliki posisi tawar untukmempengaruhi negara-negara yang lemah agar modelsosial budaya, ekonomi dan politik yang mereka 
usung sedapat mungkin disamakan disemua negara untukmempermudah pengawasan sesuai dengan kriteria yangmereka buat sepihak demi kepentingan negara-negara kuat tersebut.

Perlunya penguatan dari negara untuk mengantisipasi dampak negatif dari globalisasi, salah satunya melalui sikap nasionalisme. Pudarnya rasa nasionalisme pada masyarakat Indonesia menjadi permasalahan yang harus dihadapi oleh bangsa Indonesia. Kuatnya arus globalisasi ini dikhawatirkan menggerus perasaan cinta bangsa dan tanah air.Nasionalisme merupakan salah satu nilai luhur yang terkandung dalam Pembukaan UUD Negara Republik Indonesia 1945 dan Pancasila yang perlu diwariskan kepada generasi penerus bangsa Indonesia, dan dengan menanamkan sikap nasionalisme, diharapkan masyarakat Indonesia tumbuh menjadi manusia pembangunan yakni generasi yang mampu mengisi dan mempertahankan kemerdekaan bangsa dan negaranya. Sehingga eksistensi negara Indonesia tidak hilang begitu saja digerus oleh dampak negatif globalisasi.

Perkembangan globalisasi juga menimbulkan masalah kepada kebudayaan masyarakat Indonesia. Derasnya arus globalisasi juga mengakibatkan terkikisnya rasa cinta terhadap budaya Indonesia. Sifat yang tidak mengenal batas dari globalisasi membuat gencarnya budaya bangsa luar masuk kedalam kehidupan bangsa Indonesia. Arus globalisasi begitu cepat merasuk ke dalam masyarakat terutama di kalangan muda. Pengaruh globalisasi tersebut telah membuat banyak anak muda kita kehilangan kepribadian dan jati diri sebagai bangsa Indonesia. Hal ini ditunjukkan dengan gejala-gejala yang muncul dalam kehidupan sehari-hari anak muda pada era sekarang. Dari cara berpakaian, gaya hidup, gaya berbahasa, dan pola perilaku yang bertolak belakang dengan kebudayaan lokal bangsa Indonesia.

Upaya untuk mengatasi globalisasi yang membuat terkikisnya rasa nasionalisme dan cinta budaya Indonesia tentunya perlu dilakukan. Salah satunya melalui jalur pendidikan formal. Menumbuhkan kembali rasa nasionalisme dan cinta budaya Indonesia pada generasi penerus bangsa, yaitu padaparasiswa, maka hal ini merupakan sebuah investasi untuk mempertahankan keutuhan bangsa dan negara dimasa depan.

Pendidikan formal memiliki peran yang penting dalam membentuk karakter generasi penerus bangsa. Melalui kegiatan belajar mengajar dalam kelas ataupun kegiatan diluar kelas. Pembelajaran di sekolah yang memegang peranan untuk menunjang terhadap pencapaian tujuan tersebut adalah melalui mata pelajaran Pendidikan Pancasila dan Kewarganegaraan yang telah diajarkan di semua jenjang pendidikan mulai dari pendidikan dasar sampai denganPerguruan Tinggi. PPKn (Pendidikan Pancasila dan Kewarganegaraan) merupakan wahana untuk mengembangkan dan melestarikan nilai luhur dan moral yang berakar pada budaya bangsa Indonesia yang diharapkan dapat diwujudkan dalam bentuk perilaku dalam kehidupan sehari-hari siswa, baik sebagai individu maupun sebagai anggota masyarakat, warga negara, dan makhluk ciptaan Tuhan Yang Maha Esa.

Kegiatan penumbuhan rasa nasionalisme dan cinta budaya Indonesia tidak hanya dapat disalurkan melalui mata pelajaran PPKn saja. Ada banyak cara yang dapat dilakukan, salah satunya melalui sebuah program sekolah yang sifatnya di luar jam pelajaran sekolah. Berdasarkan observasi 
awal di SMP Negeri 1 Batu, dalam usaha meningkatkan rasa nasionalisme dan cinta kebudayaan terdapat pada proses belajar mengajar didalam kelas dan beberapa kegiatan ekstrakulikuler. Kegiatan ekstrakulikuler itu antara lain, pramuka, paskibra, seni karawitan, pencak silat dan seni tari tradisional. Namun tidak semua siswa mengikuti ektrakulikuler tersebut. Sehingga pihak SMP Negeri 1 Batu menyusun suatu program yang sifatnya menyeluruh dan bisa dilaksanakan oleh para siswa di SMP Negeri 1 Batu. Nama program tersebuat ialah Kamis Kreasi. Kamis Kreasi adalah program yang ditujukan kepada siswa terhadap Penguatan Pendidikan Karakter (PPK) dengan menampilkan pertunjukan kreativitas dan kesenian yang dilaksanakan pada setiap hari kamis.

Pada program tersebut para siswa dituntut untuk menampilkan kreasi yang bertemakan kebudayaan asli tanah air, dan tidak diperbolehkan menampilkan pertunjukan yang berbau budaya barat. Sehingga para siswa dapat lebih mengenal budaya asli Indonesia beserta maknanya serta diharapkan mampu menumbuhkan rasa nasionalisme yang lebih baik. Program Kamis Kreasi juga dapat menjadikan siswa untuk berani tampil didepan banyak orang dan juga dapat melatih kreativitas. Berdasarkan latar belakang yang telah dikemukakan di atas rumusan masalah penelitian ini adalah : (1) Bagaimana penumbuhan rasa nasionalisme siswa SMPN 1 Batu melalui program“KAMSI”? (2) Bagaimana penumbuhan rasa cinta budaya Indonesia siswa SMPN 1 Batumelalui program “KAMSI”?

\section{METODE}

Menurut Sugiyono (2013: 1) penelitian kualitatif adalah metode penelitian yang digunakan untuk meneliti keadaan yang alamiah. Peneliti merupakan instrumen kunci yang mengumpulan data secara triangulasi (gabungan), analisis data bersifat induktif dan hasil dari penelitian lebih menekankan makna dari generalisasi.

Penelitian ini penulis menggunakan jenis penelitian deskriptif melalui metode kualitatif yaitu memberikan gambaran tentang masalah yang diteliti terkait bagaimana penumbuhan rasa nasionalisme dan cinta budaya Indonesia pada siswa melalui Program Kamsi di SMP Negeri 1 Batu. Peneliti menggunakan jenis penelitian ini karena penelitian kualitatif digunakan untuk meneliti suatu perilaku dan tindakan suatu organisasi dalam upaya mengumpulkan data sebanyak-banyaknya mengenai penumbuhan nasionalisme dan cinta budaya Indonesia pada siswa melalui Program Kamsi di SMP Negeri 1 Batu yang menjadi fokus perhatian peneliti. Peneliti menghasilkan data-data deskriptif berupa kata-kata tertulis dari prilaku orang yang diamati, yang kemudian data tersebut yang telah diperoleh di lapangan dikumpulkan dalam bentuk data-data seperti kata maupun prilaku dan kalimat, dengan latar belakang alamiah yang mana manusia merupakan instrumennya.

Tempat penelitian ini berada di SMP Negeri 1 Batu yang beralamatkan di Jalan Agus Salim Nomor 55 Kota Batu. Tempat ini dipilih berdasarkan observasi sebelumnya. Adapun hasil observasi adalah sekolah tersebut menerapkan suatu Program unggulan dibidang kesenian dan kreativitas pada siswa. Waktu pelaksanaan penelitian pada tanggal 02 April 2018 s.d 10 Mei 2018.

Prosedur penelitian merupakan penjelasan langkah-langkah yang harus ditempuh peneliti dalam suatu penelitian. Menurut Moleong (2004:127), langkah-

Syahrul Hadiyatullah, dkk. Penumbuhan Rasa Nasionalisme dan Cinta Budaya Indonesia Melalui Program "Kamsi" Pada Siswa SMP Negeri 1 Batu 
langkah prosedur penelitian meliputi tiga hal yaitu:

Tahap Pra Lapangan penelitianyang dilakukan oleh peneliti antara lain: menentukan topik atau permasalahan, mencari informasi dan data mengenai permasalahan, merumuskan masalah penelitian, , menyusun pedoman observasi dan wawancara, mencari subjek dan tempat penelitian.

Tahap ini peneliti berusaha mempersiapkan diri untuk menggali dan mengumpulkan data-data untuk dibuat suatu analisis data mengenai penumbuhan rasa nasionalisme dan cinta budaya Indonesia melalui Program Kamsi pada siswa SMP Negeri 1 Batu. Secara intensif setelah mengumpulkan data, selanjutnya data dikumpulkan dan disusun.

Tahap ini dilakukan dengan kegiatan yang berupa mengolah dan menganilisis data yang diperoleh dari tahap pengerjaan lapangan yang berfokus pada penumbuhan rasa nasionalisme dan cinta budaya Indonesia siswa.

Subjek penelitian adalah subjek yang dituju untuk diteliti oleh peneliti. Subjek penelitian pada penelitian ini adalah siswa siswi SMP Negeri 1 Batu ( Kelas VIII F). Pemilihan subjek tersebut berdasarkan saran dan rekomendasi dari Wakil Kepala Sekolah bagian hubungan masyarakat. Sedangkan yang menjadi objek penelitian adalah hasil dari diadakannya Program Kamsi terhadap penumbuhan rasa nasionalisme dan cinta budaya Indonesia.

Penelitian ini menggunakan metode pengumpulan data sebagai berikut: (1) Metode observasi. Metode observasi yaitu cara pengumpulan data yang dilakukan secara sistematis dan sengaja, diawali dengan mengadakan pengamatan dan pencatatan atas gejala yang sudah diteliti dengan melibatkan diri dalam latar yang sedang diteliti (Arifin,1996:10)
Penelitian menggunakan metode observasi untuk mengetahui secara langsung apa yang terdapat di lapangan tentang bagaimana penumbuhan rasa nasionalisme dan cinta budaya Indonesia melalui program kamis kreasi di SMP Negeri 1 Batu. (2) Metode wawancara. Metode ini mencakup cara yang dipergunakan seseorang untuk suatu tujuan tertentu, mencoba mendapatkan keterangan atau pendapat secara lisan langsung dari seseorang atau informan. Dengan wawancara ini kreatifitas pewawancara sangat diperlukan. Hasil wawancara banyak bergantung pada pewawancara. Pewawancara bertujuan untuk mengetahui bagaimana penumbuhan rasa nasionalisme dan cinta budaya Indonesia melalui program kamis kreasi di SMP Negeri 1 Batu dan hal-hal yang berkaitan dengan fokus penelitian. (3) Studi dokumentasi. Metode dokumentasi adalah suatu teknik yang digunakan untuk mengumpulkan data dari sumber noninsani, sumber ini terdiri dari dokumen, dan rekaman seperti surat kabar, buku harian, naskah pribadi, fotofoto, catatan kasus, dan lain sebagainya (Arifin, 1996: 82). Melalui teknik dokumentasi ini peneliti mengumpulkan data-data yang diperlukan yang ada di tempat atau lokasi penelitian.

\section{HASIL DAN PEMBAHASAN}

Pembahasan berisi tentang hasil penelitian yang dibahas oleh peneliti. Pembahasan akan dibagi dua yaitu pembahasan penumbuhan rasa nasionalisme siswa melalui program Kamsi dan penumbuhan rasa cinta budaya Indonesia siswa melalui program Kamsi.

\section{Penumbuhan Rasa Nasionalisme Siswa Melalui Program Kamsi}

Berdasarkan hasil penelitian dari metode observasi, wawancara dan studi 
dokumentasi yang telah dipaparkan bahwa rumusan masalah dan tujuan penelitian pada penelitian ini dapat terjawab. Proses penumbuhan rasa nasionalisme dijelaskan dan dilakukan melalui tercapainya indikator nasionalisme menurut Agustarini dalam Nurhayati (2013;7).

Tabel 1 Indikator Nasionalisme

\begin{tabular}{lc}
\hline \multicolumn{1}{c}{ Indikator Nasionalisme } & Pencapaian \\
\hline 1. Menjaga dan melindungi Negara & Tercapai \\
\hline 2. Sikap rela berkorban/patriotism & Tercapai \\
\hline 3. Indonesia bersatu & Tercapai \\
\hline 4. Melestarikan budaya Indonesia & Tercapai \\
\hline 5. Cinta tanah air & Tercapai \\
\hline 6. Bangga berbangsa Indonesia & Tercapai \\
\hline 7. Menjunjung tinggi nilai kemanusiaan & Tercapai \\
\hline
\end{tabular}

Indikator menjaga dan melindungi Negara tercapai dengan perwujudan bahwa para siswa menjaga kebudayaan Indonesia dengan cara menampilkan pertunjukan kreativitas dan kesenian asli Indonesia dan tidak menampilkan pertunjukan kesenian dari Negara lain, hal tersebut termasuk dalam menjaga Negara yaitu dengan menjaga aset Negara berupa seni budaya tradisional. Selanjutnya adalah tercapainya indikator sikap rela berkorban diwujudkan dengan para siswa rela berkorban waktu, pikiran dan materi demi pertunjukan Kamis Kreasi yang baik dan menarik. Indikator Indonesia bersatu dengan perwujudan dengan para siswa bersatu berlatih bersama dengan kompak tanpa membedakan suku, ras, dan agama demi tercapainya pertunjukan Kamis Kreasi yang berhasil, tanpa rasa bersatu maka tidak akan tercapainya koordinasi yang baik dalam pertunjukan Kamis Kreasi.

Indikator melestarikan budaya tercapai dengan perwujudan penampilan para siswa kelas VIII F dengan menampilkan kesenian asli Indonesia, yaitu drama teater kisah Calonarang yang berasal dari Bali dan tari tradisional Reog Ponorogo. Setelah itu indikator cinta tanah air dan bangga berbangsa Indonesia diwujudkan dengan penggunaan bahasa Indonesia yang baik dan benar dan penggunaan pakaian produk dalam negeri dalam pertunjukan, pakaian tersebut menggunakan pakaian adat yang disesuaikan dengan drama teater Calonarang dan seni tari Reog Ponorogo.

Indikator menjunjung tinggi nilai kemanusiaan diwujudkan ketika para siswa berdiskusi dan bermusyawarah bertukar pendapat ketika menentukan pertunjukan pada kegiatan Kamis Kreasi. Rasa nasionalisme pada hasil yang diperoleh pada penelitian ini tergambar dan sesuai dengan jenis-jenis Nasionalisme menurut Lisyarti (2007:28), nasionalisme tersebut adalah nasionalisme kewarganegaraan, etnis, budaya dan kenegaraan. Hal tersebut berkaitan dengan indikator Nasionalisme yang telah dipaparkan.

Hasil wawancara kepada Wakil Kepala Sekolah bagian Kesiswaan yaitu , Menurut Bapak EP program Kamis Kreasi bisa menumbuhkan rasa cinta budaya Indonesia kepada para siswa di SMP Negeri 1 Batu, hal tersebut dibuktikan dengan pementasan pada Kamis Kreasi dengan menampilkan kebudayaan khas Indonesia.

Syahrul Hadiyatullah, dkk. Penumbuhan Rasa Nasionalisme dan Cinta Budaya Indonesia Melalui Program "Kamsi" Pada Siswa SMP Negeri 1 Batu 
Hal ini juga sejalan dengan hasil wawancara yang ditujukan kepada AD yaitu siswa kelas VIII F. Menurut AD bahwa rasa Nasionalisme dapat tumbuh, berkat penampilannya pada kegiatan Kamis Kreasi tersebut. Nasionalisme tumbuh dikarenakan siswa menampilkan kebudayaan asli Indonesia, sehingga siswa merasa tumbuh perasaan mencintai tanah air. Program Kamis Kreasi juga berefek positif kepada pembelajaran akademik bagi siswa di dalam kelas, contohnya siswa yang awalnya takut dan malu untuk tampil di depan kelas ketika ditunjuk oleh guru, menjadi berani tampil dengan baik. Rasa kepercayaan diri siswa meningkat ketika mereka tampil di depan orang banyak.

\section{Penumbuhan Rasa Cinta Budaya Indonesia Melalui Program Kamsi}

Rasa cinta budaya Indonesia ditumbuhkan pada kegiatan Kamsi dengan tercapainya indikator kebudayaan menurut C. Klcukhohn dalam Koentjoroningrat (1994;2). Berikut ini tabel pencapaian indikator kebudayaan.

Tabel 2 Indikator Kebudayaan

\begin{tabular}{lll}
\hline Indikator Kebudayaan & Pencapaian \\
\hline 1. & Peralatan dan perlengkapan hidup manusia & Tercapai \\
2. & Sistem kemasyarakatan & Tercapai \\
3. & Bahasa & Tercapai \\
4. & Kesenian & Tercapai \\
5. & Sistem pengetahuan & Tercapai \\
6. & Religi & Tercapai \\
\hline
\end{tabular}

Berdasarkan indikator kebudayaan yang telah dipaparkan bahwa setiap indikator dapat tercapai. Indikator perlengkapan dan peralatan hidup manusia diwujudkan dengan pementasan Kamis Kreasi yang menggunakan peralatan tradisional khas Indonesia, peralatan itu berupa alat musik gamelan bali dan jawa pada pementasan Calonarang dan seni tari Reog Ponorogo. Selain itu peralatan berupa pakaian adat Bali dan pakaian adat khas Jawa Timur juga digunakan dalam pementasan tersebut.

Indikator sistem kemasyarakatan tercapai dengan perwujudan para siswa yang kondisi sosial masyarakatnya berbeda antara anggota kelas dan juga masyarakat Indonesia yang memiliki system masyarakat gotong royong. Para siswa bergotongroyong dengan berlatih dan tampil pada
Kamis Kreasi dengan baik dan menarik. Indikator bahasa tercapai dengan perwujudan penggunaan bahasa yang ramah dan santun. Perwujudan dengan bahasa tersebut sesuai dengan karakteristik bangsa Indonesia yang menjungjung tinggi tata karma dan sopan santun.

Indikator kesenian tercapai dengan perwujudan kesenian yang ditampilkan adalah kesenian berupa tarian, musik dan drama teater yang berasal dari kebudayaan Indonesia. Indikator sistem pengetahuan tercapai dengan perwujudan pengetahuan tentang kebudayaan, dalam hal ini para siswa mencari tahu dan mengeksplorasi kebudayaan yang ditampilkan serta disesuaikan dengan kebudayaan yang ada di Indonesia. Selanjutnya ialah indikator religi tercapai dengan perwujudan para siswa tidak menimbulkan pertunjukan yang 
berbau unsur SARA (Suku, Agama, Ras, dan Antar golongan).

Hasil wawancara kepada Wakil Kepala Sekolah bagian Kesiswaan Menurut EP penumbuhan rasa cinta budaya Indonesia siswa ditumbuhkandengan pementasan pada Kamis Kreasi dengan menampilkan kebudayaan khas Indonesia. Serta tidak diperkenankan menampilkan kebudayaan luar negeri atau kebudayaan berasal dari budaya luar. Ketika kebudayaan khas Indonesia ditampilkan maka siswa akan menghayati kebudayaan tersebut, sehingga tentu saja dapat menumbuhkan kecintaan terhadap budaya asli Indonesia.

Hal ini juga sejalan dengan hasil wawancara yang ditujukan kepada Abdullah Dhani yaitu siswa kelas VIII F. Menurut AD bahwa cinta budaya Indonesia dapat tumbuh, berkat penampilannya pada kegiatan Kamis Kreasi tersebut bahwa Abdullah Dhani semakin penasaran tentang kebudayaan daerah lain yang ada di Indonesia sehingga membuatnya ingin belajar lagi tentang kebudayaan dari daerah lain.

Pelaksanaan Program Kamis Kreasi juga mengalami hambatan. Hambatan itu berupa seringnya siswa mengambil jam pelajaran untuk digunakan sebagai waktu latihan, tentunya hal ini dapat mengganggu kegiatan belajar mengajar dalam kelas. Namun hal itu dapat ditanggulangi dengan saling berkoordinasinya guru kelas dan Wakil Kepala Sekolah bagian Kesiwaan agar para siswa mengambil jam latihan di luar jam pelajaran sekolah. Hambatan pada siswa menurut AD yaitu ketua kelas VIII F ialah ada saja anggota kelas yang malas dan tidak bisa hadir ketika latihan dilaksanakan, namun hambatan itu bisa dilalui dengan saling berkoordinasinya para anggota kelas dalam berlatih, sehingga semua siswa dapat berlatih bersama dengan baik. Menurut kedua informan tersebut, bahwa orang tua siswa juga sangat antusias terhadap Program Kamis Kreasi. Para orang tua siswa sangat mendukung program ini, bahkan orang tua siswa tidak segan untuk mengeluarkan dana dan sumbangan kepada para siswa agar penampilan siswa pada kegiatan Kamis Kreasi berjalan baik dan menarik.

Nasionalisme dan cinta budaya Indonesia berkaitan dengan pembelajaran PPKn. Pembelajaran PPKn yang inti ajarannya menurut PP Nomor 32 tahun 2013 adalah sebagai wadah untuk menjadikan manusia Indonesia untuk lebih mencintai budaya bangsanya dan sebagai sarana untuk membangun rasa nasionalisme. Hal tersebut tidak bertentangan pada kegiatan Kamis Kreasi. Kamis kreasi justru dapat dijadikan sarana untuk pengaplikasian manusia Indonesia yang mencintai budaya dan membangun rasa nasionalisme. Menurut hasil penelitian yang diperoleh bahwa rasa Nasionalisme dan cinta budaya Indonesia dapat tumbuh, sehingga tujuan pembelajaran PPKn saling berkaitan dengan Program Kamis Kreasi.

Era pemerintahan presiden Ir. Joko Widodo pada saat ini ialah mengembangkan pendidikan penguatan karakter. Pendidikan karakter menjadi salah satu hal yang diutamakan. Dasar hukum ditetapkannya Program Penguatan Pendidikan Karakter adalah Perpres Nomor 87 Tahun 2017 tentang Penguatan Pendidikan Karakter. Pengembangan karakter RENAMAGI (Religius, Nasionalis. Mandiri, gotong royong dan integritas) dapat dituangkan pada kegiatan Kamis Kreasi. Berdasarkan hasil penelitian yang diperoleh bahwa kelima karakter

Syahrul Hadiyatullah, dkk. Penumbuhan Rasa Nasionalisme dan Cinta Budaya Indonesia Melalui Program "Kamsi" Pada Siswa SMP Negeri 1 Batu 
tersebut tercapai pada penelitian ini tentang Nasionalisme dan cinta budaya Indonesia. Karakter nasionalis dan integritas tercapai dengan tercapainya indikator nasionalisme yang telah dipaparkan di atas, sedangkan karakter religius, mandiri, dan gotong royong tercapai dengan cakupan indikator kebudayaan yang telah dipaparkan di atas.

\section{SIMPULAN}

Berdasarkaan hasil dan pembahasan penelitian yang terdapat pada bab IV, maka dapat disimpulkan: Penumbuhan rasa nasionalisme dan cinta budaya Indonesia siswa melalui Program Kamsi ditumbuhkan melalui proses latihan dan penampilan drama teater Calonarang dan seni tari Reog Ponorogo. Proses latihan dan penampilan tersebut telah memenuhi indikator nasionalisme dan indikator kebudayaan.

\section{DAFTAR PUSTAKA}

Arifin. 1996. Penelitian Kualitatif dalam ilmu-ilmu Sosial dan Keagamaan. Malang: Kalimas sahada.

Lisyarti, Retno. 2007. Pendidikan Kewarganegraanuntuk SMA dan MA Kelas $\quad X$, Jakarta: Erlangga.

Nurhayati, Yanti. 2013. Pengaruh Upacara Bendera Terhadap Sikap NasionalismeDi SMPN 14 Bandung.Bandung:Universitas Pendidikan Indonesia.

PP Nomor 32 Tahun 2013 tentang Standar Nasional Pendidikan.

Perpres Nomor 87 Tahun 2017 tentang Penguatan Pendidikan Karakter.

Sugiyono, P. D. 2013. Metode Penelitian Manajemen. Bandung: CV Alfabeta. Sujanto, Bedjo. 2007. Pemahaman Kembali makna Bhineka Tunggal Ika . Jakarta: CV Sagung Seto. 